\title{
Actions by the Brazilian Government Regarding Elderlies' Conditions in Times of COVID-19
}

\section{Rodrigues $\mathrm{AT}^{1 *}$ and Silva SM${ }^{2}$}

${ }^{1}$ Doctor in Interdisciplinary Studies on Women Gender and Feminism, Master in Education and Majored in Philosophy at the Federal University of Bahia, Brazil

${ }^{2}$ Doctorate on Interdisciplinary Studies on Women Gender and Feminism, Federal University of Bahia, Brazil

*Corresponding author: Alexnaldo Teixeira Rodrigues, Professor at Visconde de Cairu Foundation; Doctor in Interdisciplinary Studies on Women Gender and Feminism, Master in Education and Majored in Philosophy at the Federal University of Bahia, Brazil, Email: alexnaldo@cairu.br

\section{Commentary}

\section{Introduction}

Brazil, as well as other countries, is facing a health crisis due to the pandemic of Covid-19. In this context, many lives have been cut short because of entanglements of the contagion. Among people that have been contaminated, a great number is of elderlies, whose deaths add to the increase of figures, which have already reached the number of 247 thousand people, being that more than 100 thousand of them are older than 60 years of age (BRASIL, 2021). Whereupon, and under feminist perspectives, we aim to identify and analyze the main actions of the Brazilian Executive Power to this specific public.

\section{Federal Executive Power before the elderly Population in the Pandemic Context}

Constitutionally speaking, it is duty of the Federal Executive Power the responsibility with most of the measures related to the prevention and coping of the pandemic, especially the Ministries of Health, Economy, Women, Family and Human Rights, among others, all of them under the command of the Presidency of Republic. Nevertheless, President Jair Bolsonaro publicly declared that elderlies "cannot be in the accounts of the State" [1]. Since the start of the pandemic, the institutional environment has been filled with conflicts, especially ethical ones, which are related to sensible issues, such as environment, indigenous people, education, among others, and that are dealt simultaneously with the health crisis and which, the same way, need attention from the State. A political and economic agenda is added to this situation, which does not consider the pandemic effects under a humanitarian perspective, by denying that there are ethical conflicts, but only distinct priorities. However, as said by Krenak A, et al. [2]: "[...] economy is an activity that had been invented by human beings and that depend on us. If human beings are under risk, any human activity does not have any importance anymore. To say that the economy is more important is like saying that the vessel is more important than the crew".

Regarding the health measures, the Health Ministry adopted, since the beginning, the recommendations by WHO, especially while minister Mandetta was ahead of office, nevertheless the innumerable conflicts between him and President Bolsonaro, whose statements in face of the pandemic do not conflict with the elementary scientific guidelines, in the health area, but also clash with the expectations and fears of most of the population, even regarding the elderly's safety measures, once the President yet defends that only this social category, and the ones who are facing chronicle disease and may be isolated, not considering the reality of most of Brazilian elderlies who, often, live with big families in small houses and precarious infrastructure. Or, when they live alone, depend on outsiders to help them with basic needs, not forgetting the ones who live in philanthropic institutions or on the streets, as shown by a recent survey of the overview of elderlies in Brazil (NERI, 2020). Then, just isolating the elderly people, would be ignoring the country's reality itself, and the precarious life 


\section{Annals of Bioethics \& Clinical Applications}

conditions of most of the Brazilian families.

Consequently, and considering the speeches made by Minister Damares Alves, who assures that " no elderly in Brazil will die alone" Ohana V, et al. [3], the speech by the National Secretary of Promotion and Defense of the Rights of the Elderlies, Antônio Costa, which were stated on a live broadcast on April 22, 2020, do not hide the non-existence of more effective and coordinated action that fulfill the demands of elderlies under this context, especially the most excluded and vulnerable ones, in different regions in the country. Moreover, the Secretary's speech also points out the budgetary shortage that impedes the supply of basic materials in the Institutions of Long Stay for Elderlies (Instituições de Longa Permanência para Idosos-ILPI), which are responsible for housing elderlies who do not have physical, mental, social or even economic conditions to support and take care of themselves during old age. According to the Secretary, there are not actions by the Federal Government for elderlies who are not housed in institutions because, beyond the meagre budget, families, member states and municipalities are already taking care of them; it shows a non-acceptable excuse, because all the laws related to the protection of the elderly population, talk about joint actions by the family, the society and the State.

It is, then, a picture of state non-assistance that has been outlined for a long time, and that has aggravated and got much bigger during this pandemic, and which shows much more about the omission by the State with the elderly population, than its punctual, shy and non-articulated action along the terms of the most diverse governments.

\section{For an Ethic of care and otherness in the State Actions: Elderlies' Lives Matter}

The above-mentioned facts reflect the hegemonic view on the old age that has been built along the years in this country and, as well as, other ones, which is characterized, in a negative and prejudiced way, since this life stage is still very associated to non-productivity, dependency and onerability for the families and for the State. And all of this, in a certain way, explains the social and State disregard and deportation faced by elderlies, not forgetting that many families do not want Leitão KA, et al. [4] and/or do not have means and resources to take care of their elderlies. It is under this aspect that the philosophical reflections on feminist matrix on ethic and care and on respect to otherness are excellent tools of problematization and guidance of public or individual action, once, accordingly, highlight some works and authors; the elderly population is included among the individuals, as socially disposable, albeit their vulnerability or precarious conditions of life result, in most cases, from the social and state omission itself, once, many times, they are dehumanized and inconsiderate, with a view to justify their invisibility and even their elimination.

The ethic of care while feminist standard should serve as the fundament of public policies, before, during and after the pandemic, once this new ontological perspective allows the evidence of inequality, vulnerability and human interdependence, bringing into discussion the precarious contexts, through an epistemology that push the resignation of attitudes of indifference or of supposed neutrality in the social observation and in the conception and execution of state policies. In addition, it leads us to a responsibility that is understood as support, assistance and protection of the individual and of the community, so that we can live as well as possible John CT, et al. [5]. Therefore, the public institutions and policies, when accommodating the care practices would contribute to resignify concepts and practices which, almost always, are distanced from the political sphere, as for example affection, compassion, solidarity and care, and which would help individuals to recognize them as social and moral goodness.

On a derivative mode, the perspective of ethic in question, also faces aspects of neoliberal policies, which need to be discussed and criticized in the context of Convid-19, especially in a country such as Brazil, whose legal norms in favor of the elderly population were not even been completely observed before the advent of the pandemic.

Since the perspective of ethic and policy of care, there has been made criticism to the notion of individual of the classic political theory and of neoliberal practice, regarded, ontologically, as self-restrained and autonomous entity, owner of himself, or, better, owing nothing to a network of social relationships. It is this ideology and neoliberal practice that attributes to the individuals, regarded as independent, free and autonomous, the liberal power to be exempted from the health care, mas not for not deciding on their allocation, according to highlighted critical reflections to which we agree on Batista SA, et al. [6]. The State also does it, as a political entity, when seeing the old age as a problem of the families, and not as a responsibility of all, objectifying the old individual and, the same way hindering the recognition that the public life is not extinct or depleted with the advent of the old age [7]. The State action, according to the ethic in question, shall consider care as a pillar of social security, and shall not be exempted from the responsibility, even because, one of the most perverse dimensions that distinguish the current neoliberal phase, is the invisibility of the big majorities of poor and oppressed people [8], seen as zero economic ones, and felt as non-participant of mankind. Because of it, the care in its political dimension, shall propel the public power, since the prevention, going through full assistance to the victims of Covid-19 [9,10], until reaching an attitude of vigilance 


\section{Annals of Bioethics \& Clinical Applications}

and sheltering, that is, to new protective irradiations and maintainers of life Leonardo B, et al. [10].

\section{References}

1. Fernandesn A (2020) Families that take care of their elderly', says Bolsonaro about opening shops. Estado De Minas national.

2. Ailton K (2020) Krenak: Tomorrow is not for sale. Other Words.

3. Ohana V (2020) Damares promises that the elderly will not die abandoned by covid-19. Carta Captial.

4. Leitão KA (2011) Civil liability: the emotional and material abandonment of children in relation to elderly parents. State University of Ceará/Escola Superior Do Ministério Público. ESMP monographs. Fortaleza.
5. John CT, Berenice F (1990) Toward a feminist theory of care. Circles of care. Albany (NY): University of New York Press, pp: 35-62.

6. Batista SA, Bandeira LM (2015) Care work: a situational and multidimensional concept. Revista Brasileira de Ciência Política 18: 59-80.

7. (2020) Boletim Epidemiológico Especial: Doença pelo Coronavírus COVID-19. Ministério da Saúde Secretaria de Vigilância em Saúde 53: 1-76.

8. Carol G (1993) In a Different Voice: Psychological Theory and Women's Development. Harvard University Press.

9. LIVE: Elderly person. Minister Damares and Antônio Costa.

10. Leonardo B (2012) The necessary care: in life, health, education, ecology, ethics and spirituality. Petrópolis, RJ: Voices. 